\title{
Analisis Kelayakan Usaha Produksi Pertashop Pertamina dengan Studi Kasus pada PT Riken Engineering Perkasa
}

\author{
Candra Galang Gemilang Putra ${ }^{1 *}$, Wahyudin ${ }^{2}$ \\ 1,2Program Studi Teknik Industri, Universitas Singaperbangsa Karawang, Karawang, Indonesia \\ (*andragalang28@gmail.com)
}

\begin{abstract}
Abstrak - Alasan dilakukannya penelitian ini adalah untuk memutuskan kelayakan bisnis dari pembuatan Pertashop Pertamina di PT Riken Engineering Perkasa dilihat dari sudut pandang aspek non finansial yaitu aspek hukum, aspek pasar dan pemasaran, aspek teknis dan teknologi, serta aspek lingkungan hidup dan aspek finansial yang dianalisis dengan metode payback period (PP), net present value (NPV), profitability index (PI), internal rate of return (IRR), dan average rate of return (ARR). Penelitian ini merupakan penelitian deskriptif kualitatifkuantitatif. Subyek penelitian ini adalah PT Riken Engineering Perkasa dan objek eksplorasi adalah kelayakan usaha produksi Pertashop Pertamina. Strategi pemerolehan informasi dilakukan dengan metode wawancara dan dokumentasi. Prosedur pemeriksaan informasi dari eksplorasi ini adalah penyelidikan subjektif untuk mengevaluasi perspektif hukum, sudut pasar dan periklanan, sudut pandang khusus dan mekanis seperti sudut ekologis, dan penyelidikan kuantitatif untuk survei sudut pandang moneter. Hasil pemeriksaan ini menunjukkan bahwa: (1) dari segi hukum produksi Pertashop Pertamina sangat memungkinkan untuk dijalankan, (2) dari bagian pasar dan iklan kreasi Pertashop Pertamina dinyatakan sepenuhnya dapat dicapai menjalankan, (3) menurut aspek pasar dan pemasaran produksi Pertashop Pertamina dinyatakan sangat layak untuk dijalankan, (4) Berdasarkan aspek lingkungan hidup PT Riken Engineering Perkasa layak untuk dijalankan, dan (5) dari segi finansial, produksi Pertashop Pertamina dinyatakan layak untuk dijalankan.
\end{abstract}

Kata kunci: aspek finansial; aspek non finansial; kelayakan usaha; Pertashop Pertamina

\section{PENDAHULUAN}

PT Riken Engineering Perkasa merupakan perusahaan berbadan hukum persero terbatas (PT) di bidang fabrication, machining, welding, civil, contruction, dan consultan engineering. Perusahaan ini termasuk ke dalam perusahaan made by order yang artinya produk yang diproduksi merupakan pesanan konsumen perusahaan, dan produk akan diproduksi setelah pesanan masuk, sehingga perusahaan tidak menyediakan stok produk atau ready stock. Produk yang dikerjakan PT Riken Engineering Perkasa meliputi bahan logam yang melibatkan permesinan. Salah satu produk yang sedang diproduksi oleh PT Riken Engineering Perkasa adalah Pertashop Pertamina, produk tersebut merupakan pesanan dari PT Pindad Persero yang nantinya digunakan oleh PT Pertamina. Penulis mencoba menganalisa tingkat kelayakan usaha perusahaan PT Riken Engineering Perkasa pada produksi Pertashop Pertamina karena produksi tersebut menghadapi keterbatasan dalam pemanfaatan yang menggabungkan bahan mentah, pekerja, energi dan berbagai sumber daya yang menyebabkan pemborosan produksi sehingga kurang layak dan efektif dalam penggunaannya.

\section{STUDI LITERATUR}

\section{A. Pertashop Pertamina}

Pertamina meluncurkan layanan berupa Pertashop. Pada dasarnya Pertashop adalah produk dispersi dari Pertamina yang siap melayani pembeli yang belum terlayani oleh Lembaga penyalur BBM, misalnya seperti SPBU. Section Head Communication \& Relations Pertamina Marketing Operation Region (MOR) V, Ahad Rahedi menilai Pertashop ini menghadirkan SPBU versi sederhana (Azanella, 2020).

Dalam pembuatan Pertashop Pertamina, terdiri dari beberapa komponen berdasarkan proses pembuatan, adapun tahapan dari proses pembuatannya diantaranya sebagai berikut: (1) Tangki Outer \& Penetrant (NDT), (2) Tangki Inner \& Penetrant (NDT), (3) Base, (4) Frame \& Dudukan Tangki, (5) Pipa Inlet, (6) Pipa Outlet, (7) Box Assy, (8) Rumah Rolling Door, (9) Frame ACP, (10) Base Frame Assy, (11) Frame Eternit Assy, (12) Shelter Assy, (13) Tangki Assy, dan (14) ACP. 


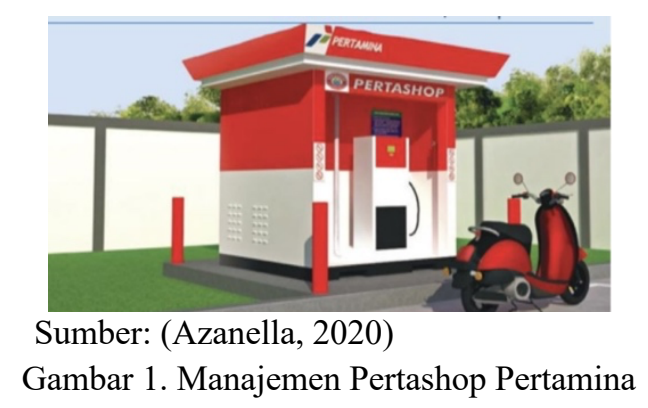

\section{B. Studi-Kelayakan-Bisnis}

1. Pengertian Studi Kelayakan Bisnis

Studi kelayakan bisnis adalah penelitian tentang dapat tidaknya suatu proyek (biasanya berupa proyek investasi) dilaksanakan dengan berhasil (Afiyah, 2015). Dalam hal ini proyek mempunyai arti suatu pendirian usaha baru atau pengenalan produk baru. Menurut Kasmir (2012), studi kelayakan bisnis merupakan suatu kegiatan menganalisis secara mendalam mengenai suatu usaha atau bisnis yang sedang dijalankan untuk menentukan layak atau tidak usaha dijalankan. (Tanaka, 2017) menyatakan bahwa studi kelayakan bisnis merupakan penelitian terhadap rencana bisnis yang tidak hanya menganalisis layak atau tidak layak suatu bisnis dibangun tetapi juga saat dioperasionalkan secara rutin dalam rangka pencapaian keuntungan yang maksimal untuk waktu yang tidak ditentukan. Dengan demikian, dapat disimpulkan bahwa studi kelayakan bisnis merupakan kegiatan analisis layak atau tidak rencana bisnis dan saat bisnis dioperasionalkan secara rutin dalam mencapai tujuan yang diinginkan (Rahayu, 2015). Menurut Purnamasari (2013), dengan kondisi lingkungan yang sangat dinamis dan intensitas persaingan yang semakin ketat, tidaklah cukup jika hanya mengandalkan pengalaman dan intuisi dalam memulai usaha. Oleh karena itu, pengusaha dituntut untuk melakukan studi kelayakan terhadap ide bisnis yang akan dijalankan. Laporan hasil analisis kelayakan bisnis sangat diperlukan dalam proses pengambilan keputusan investasi karena dapat memberikan gambaran mengenai prospek tingkat manfaat yang diterima dari bisnis yang akan dijalankan. Menurut Musmulyadi (2020), pihak-pihak yang membutuhkan laporan studi kelayakan bisnis sebagai berikut: (1) Pihak investor, (2) Pihak kreditor, (3) Pihak manajemen Perusahaan, (4) Pihak pemerintahan dan masyarakat, (5) Bagi tujuan pembangunan ekonomi.

\section{Tujuan Studi Kelayakan Bisnis}

Menurut Kasmir (2012), studi kelayakan bisnis dilakukan agar proyek yang dijalankan tidak sia-sia. Dengan kata lain, proyek yang dijalankan tidak membuang waktu, tenaga, dan pikiran secara percuma serta menimbulkan masalah di masa yang akan datang. Terdapat lima tujuan penyusunan studi kelayakan bisnis suatu proyek sebelum dijalankan (Kasmir, 2012), yaitu: (1) Menghindari risiko kerugian karena masa mendatang penuh ketidakpastian, (2) Memudahkan perencanaan terkait jumlah dana yang diperlukan, kapan usaha atau proyek dijalankan, di mana lokasi proyek akan dibangun, siapa yang akan melaksanakannya, bagaimana cara menjalankannya, dan berapa keuntungan yang akan diperoleh, (3) Memudahkan pelaksanaan pekerjaan karena telah disusun berbagai rencana dalam pelaksanaan bisnis, (4) Memudahkan pengawasan karena pelaksanaan proyek didasarkan pada rencana yang telah dibuat, dan memudahkan pengendalian sehingga jika terjadi penyimpangan akan mudah terdeteksi dan segera dilakukan perbaikan.

\section{Tahapan Studi Kelayakan Bisnis}

Tahapan dalam melakukan studi kelayakan bisnis perlu dilakukan dengan benar agar tujuan yang ditetapkan tercapai. Tahapan dalam studi kelayakan bisnis dilakukan untuk mempermudah pelaksanaan studi kelayakan dan keakuratan penilaian. Secara umum studi kelayakan bisnis meliputi langkah-langkah sebagai berikut (Handjojo, 2017): (1) Penemuan ide bisnis, (2) Melakukan studi pendahuluan, (3) Membuat desain studi kelayakan, (4) Pengumpulan data, (5) Analisis dan interpretasi data, (6) Menarik kesimpulan dan rekomendasi, (7) Penyusunan laporan studi kelayakan bisnis.

4. Aspek Penilaian Bisnis

Untuk memperoleh kesimpulan yang kuat mengenai dijalankan atau tidaknya sebuah ide bisnis, aspekaspek yang perlu dilakukan studi kelayakan meliputi aspek hukum, aspek lingkungan, aspek pasar dan 
pemasaran, aspek teknis dan teknologi, aspek manajemen dan sumber daya manusia, dan aspek finansial (Amilia, 2017). Menambahkan aspek ekonomi dan sosial dalam penilaian kelayakan bisnis (Kasmir, 2012). Aspek-aspek penilaian bisnis tersebut dijelaskan sebagai berikut:

a. Aspek Hukum

Aspek hukum berkaitan dengan legalitas perusahaan yang mencakup bentuk badan usaha dan perizinan yang harus dipenuhi oleh perusahaan. Analisis aspek hukum dilakukan untuk mengetahui kemampuan pelaku bisnis dalam memenuhi ketentuan hukum dana perizinan yang diperlukan dalam menjalankan bisnis di wilayah tertentu (Winantara, 2014). Ketentuan hukum untuk setiap jenis usaha berbeda-beda, tergantung pada kompleksitas bisnis tersebut. Kelengkapan keabsahan dokumen sangat penting sebagai dasar hukum apabila terjadi masalah di kemudian hari (Kasmir, 2012). Izin yang perlu dianalisis adalah sebagai berikut (Fitriani, 2013): (1) Akta Pendirian Perusahaan, (2) Nomor Pokok Wajib Pajak (NPWP), (3) Surat Izin Usaha Perdagangan (SIUP), (4) Surat Izin Tempat Usaha (SITU), (5) Surat Izin Usaha Industri (SIUI), (6) Surat Keterangan Domisili Perusahaan (SKDP), dan (7) Tanda Daftar Perusahaan (TDP).

b. Keberadaan bisnis dapat berpengaruh terhadap lingkungan, baik lingkungan masyarakat maupun lingkungan ekologi (Rahmadani, 2019). Dengan melakukan analisis aspek lingkungan, maka akan diketahui pengaruh atau dampak yang ditimbulkan dari bisnis yang dijalankan dan penanganan yang dilakukan (Kasmir, 2012). Kesalahan dalam penilaian aspek lingkungan akan berdampak negatif di kemudian hari, seperti terjadinya protes dari masyarakat, permintaan uang ganti rugi, dan tuntutan penghentian usaha (Arianton, 2019). Oleh karena itu, analisis lingkungan perlu dilakukan untuk mengetahui dampak yang ditimbulkan perusahaan terhadap lingkungan sosial, lingkungan ekonomi, dan lingkungan fisik.

c. Aspek pemasaran berkaitan dengan aktivitas yang dilakukan perusahaan untuk menciptakan, meningkatkan dan mempertahankan penjualan produk. Aspek pasar dan pemasaran dianalisis untuk mengetahui seberapa besar potensi pasar untuk produk yang ditawarkan dan marketashare yang dikuasai pesaing (Kasmir, 2012). Dalam aspek ini juga dirumuskan strategi pemasaran yang akan dijalankan dengan melakukan riset pasar atau mengumpulkan data dari berbagai sumber. Kegiatan bisnis diharapkan dapat berjalan dengan baik dan produk mendapatkan tempat di pasar sehingga menghasilkan penjualan dan keuntungan. Aspek pasar dan pemasaran terdapat bauran pemasaran yang membantu menganalisis 4P, yaitu produk (product), harga (price), promosi (promotion), dan tempat/ distribusi (place) (Arifudin, 2020).

d. Aspek teknologi berkaitan dengan teknologi atau serangkaian peralatan yang digunakan untuk mendukung aktivitas usaha. Dalam aspek teknis dan teknologi yang akan dianalisis adalah mengenai lokasi usaha, baik kantor pusat, cabang, pabrik, maupun gudang dengan mempertimbangkan kedekatan dengan pasar, penyedia bahan baku, tenaga kerja, dan menilai proses produksi (Rinofah, 2016).

e. Aspek finansial dianalisis untuk mengetahui jumlah biaya yang akan dikeluarkan dan pendapatan yang akan diterima serta menentukan proporsi pemenuhan sumber dana, yaitu melalui pinjaman, modal sendiri, atau investor. Terdapat tiga kegiatan utama penilaian aspek finansial, yaitu membuat rekap penerimaan, membuat rekap biaya, dan menguji aliran kas masuk yang dihasilkan berdasarkan kriteria kelayakan yang ada (Sapmaya Wulan, 2016). Metode penilaian yang digunakan sebagai berikut: (1) Payback Period (PP), (2) Net Present Value (NPV), (3) Profitability Index (PI), (4) Internal Rate of Return (IRR), dan (5) Average Rate of Return (ARR) (Yusri Nadya, 2018).

\section{METODOLOGI}

\section{A. Tempat dan Waktu Pelaksanaan}

Penelitian ini dilakukan di PT Riken Engineering Perkasa yang menjadi sampel penelitian. Adapun waktu penelitian dilaksanakan pada bulan Maret sampai dengan Juni 2021 selama kurang lebih 3 bulan dengan waktu pengamatan efektif selama satu bulan, Adapun untuk selebihnya merupakan waktu untuk perizinan melakukan penelitian dan melengkapi data penelitian yang kurang. 


\section{B. Subjek dan Objek Penelitian}

Subjek yang diteliti dalam penelitian ini adalah PT Riken Engineering Perkasa. Objek penelitian ini adalah kelayakan usaha proyek pembuatan Pertashop milik Pertamina pesanan dari PT Pindad (Persero) kepada PT Riken Engineering Perkasa ditinjau dari aspek nonfinansial yang meliputi aspek hukum, aspek pasar dan pemasaran, aspek teknis dan teknologi, serta aspek lingkungan hidup dan aspek finansial yang dihitung dengan payback period (PP), net present value (NPV), profitability index (PI), internal rate of return (IRR), dan average rate of return (ARR).

\section{Populasi dan Sampel}

Populasi dalam penelitian ini adalah karyawan yang bekerja di PT Riken Engineering Perkasa. Berdasarkan data tahun 2021, populasi penelitian ini sebanyak 25 karyawan. Sampel penelitian ini dilakukan dengan teknik purposive sampling, yaitu teknik penentuan sampel dengan berbagai pertimbangan dan kriteria tertentu sesuai kehendak peneliti (Sugiyono, 2008:61). Diperoleh sampel penelitian sebanyak 9 pekerja PT Riken Engineering Perkasa. Seluruh sampel merupakan karyawan tetap dari PT Riken Engineering Perkasa yang difokuskan kepada departemen fabrication di produksi Pertashop Pertamina.

\section{Teknik dan Instrumen Pengumpulan Data}

Jenis data dalam penelitian ini adalah data primer dan data sekunder. Metode pengumpulan data primer dilakukan dengan teknik wawancara. Sedangkan data sekunder diperoleh dari dokumen-dokumen perusahaan yang diperlukan dalam penelitian dan internet. Metode pengumpulan data dapat dijelaskan sebagai berikut:

1. Teknik Wawancara: Wawancara dilakukan untuk mendapatkan data secara langsung dari subjek penelitian, yaitu HRD, PPIC, Engineer, dan Kepala Departemen PT Riken Engineering Perkasa. Teknik wawancara dilakukan untuk memperoleh data mengenai seluruh aspek yang diteliti yang kemudian didukung dengan teknik dokumentasi.

2. Teknik Dokumentasi: Pengumpulan data dengan menggunakan dokumen-dokumen, catatan dan laporan yang dimiliki perusahaan serta angket tertutup berbentuk checklist dan tabel. Angket diisi oleh peneliti berdasarkan jawaban dari sampel penelitian ketika wawancara dilakukan.

\section{E. Teknik Analisis Data}

Pengolahan data dalam penelitian ini dilakukan secara kualitatif dan kuantitatif. Pengolahan data kualitatif digunakan untuk menganalisis aspek-aspek non finansial yang meliputi aspek hukum, aspek pasar dan pemasaran, aspek teknis dan teknologi, serta aspek lingkungan hidup. Sedangkan pengolahan data kuantitatif dilakukan untuk menganalisis aspek finansial dengan menghitung payback period ( $\mathrm{PP})$, net present value (NPV), profitability index (PI), internal rate of return (IRR), dan average rate of return (ARR).

1. Aspek Hukum: Berikut ini kriteria penilaian kelayakan usaha yang digunakan dalam analisis aspek hukum: (1) Akta Pendirian Perusahaan, (2) Nomor Pokok Wajib Pajak (NPWP), (3) Surat Izin Usaha Perdagangan (SIUP), (4) Surat Izin Tempat Usaha (SITU), (5) Surat Izin Usaha Industri (SIUI), (6) Surat Keterangan Domisili Perusahaan (SKDP), dan (7) Tanda Daftar Perusahaan (TDP).

2. Aspek Pasar dan Pemasaran: Berikut ini kriteria penilaian kelayakan usaha yang digunakan dalam aspek pasar dan pemasaran: (1) Tersedianya pangsa pasar ditandai dengan pesanan milik Pertamina Indonesia melalui PT Pindad (Persero), (2) Produk memiliki desain serta rancangan yang telah ditentukan serta memiliki standar pembuatan Pertashop, (3) Harga jual stabil, dan (4) Saluran distribusi sudah tepat, yaitu semua hasil produksi Pertashop dijual kepada PT. Pindad (Persero).

3. Aspek Teknis dan Teknologi: (1) Bahan untuk komponen utama dan komponen tambahan dapat diperoleh dengan mudah, (2) Bahan untuk komponen utama dan komponen tambahan tersedia paling tidak sampai waktu perkiraan pengembalian investasi, (3) Tenaga kerja yang dimiliki sesuai dengan kebutuhan perusahaan, (4) Karyawan menggunakan alat keselamatan kerja yang memenuhi standar, yaitu penutup kepala, masker, sarung tangan, dan sepatu tertutup, (5) Ruang dan proses penyimpanan produk sesuai dengan standar yang ditentukan, yaitu: (a) Ruangan bersih dan sirkulasi udara baik, (b) Ruangan kering dan tidak rawan terkena air, (c) Produk yang disimpan diberi alas dan (6) Peralatan yang dibutuhkan sudah dimiliki dan sesuai dengan standar yang ditetapkan PT Riken Engineering Perkasa. 
4. Aspek Lingkungan Hidup: Berikut ini kriteria penilaian kelayakan usaha yang digunakan dalam aspek lingkungan hidup: (1) Tidak menghasilkan limbah yang mengakibatkan ketidaksuburan tanah, (2) Tidak menghasilkan limbah yang mengakibatkan perubahan warna, rasa dan bau air, (3) Tidak menghasilkan limbah yang mengakibatkan polusi udara. dan (4) Tidak menghasilkan limbah yang mengakibatkan polusi suara.

5. Aspek Finansial: Aspek finansial dianalisis menggunakan 5 metode sebagai berikut: (1) Payback Period (PP), (2) Net Present Value (NPV), (3) Profitability Index (PI), (4) Internal Rate of Return (IRR), dan (5) Average Rate of Return (ARR)

\section{HASIL DAN DISKUSI}

\section{A. Analisis}

Aspek yang dianalisis dalam penelitian ini adalah aspek hukum, aspek pasar dan pemasaran, aspek teknis dan teknologi, aspek lingkungan hidup, dan aspek finansial.

Tabel 1

Analisis kelayakan usaha

\begin{tabular}{llccc}
\hline \multirow{4}{*}{ No Analisis Aspek Kelayakan Usaha } \\
\cline { 2 - 5 } & \multicolumn{1}{c}{ Aspek Kelayakan Usaha } & $\begin{array}{c}\text { Kriteria } \\
\text { Terpenuhi }\end{array}$ & $\begin{array}{c}\text { Kriteria Tidak } \\
\text { Terpenuhi }\end{array}$ & $\%$ \\
\hline 1 & Aspek Hukum & 7 & 0 & 100 \\
2 & Aspek Pasar dan Pemasaran & 4 & 0 & 100 \\
3 & Aspek Teknis dan Teknologi & 8 & 2 & 80 \\
4 & Aspek Lingkungan Hidup & 3 & 1 & 75 \\
5 & Aspek Finansial & 4 & 1 & 80 \\
\hline
\end{tabular}

Sumber: (Data Penelitian, 2021)

Berdasarkan penelitian yang telah dilakukan terhadap ke-5 aspek kelayakan usaha pada produksi Pertashop Pertamina didapati ke-5 aspek dapat dikatakan layak untuk dijalankan. Berdasarkan persentase yang tercantum pada tabel di atas didapati seluruh aspek memiliki persen kelayakan di atas 75\% dari kriteria yang telah ditentukan sebelumnya. Meski tidak semua poin dari aspek kelayakan usaha dapat dipenuhi, produksi Pertashop Pertamina dikatakan layak untuk dijalankan.

\section{B. Pembahasan}

Aspek hukum mengkaji ketentuan hukum atau perizinan yang harus dimiliki oleh suatu perusahaan. Sampel penelitian ini adalah produksi pembuatan Pertashop Pertamina pesanan dari PT Pindad (Persero) oleh PT Riken Engineering Perkasa. Aspek hukum dipenuhi oleh PT Riken Engineering Perkasa telah disahkan dengan memenuhi syarat perizinan sesuai dengan yang syarat perizinan badan usaha perseroan terbatas (PT) yang telah ditentukan, mulai dari (1) Akta Pendirian Perusahaan, (2) Nomor Pokok Wajib Pajak (NPWP), (3) Surat Izin Usaha Perdagangan (SIUP), (4) Surat Izin Tempat Usaha (SITU), (5) Surat Izin Usaha Industri (SIUI), (6) Surat Keterangan Domisili Perusahaan (SKDP), dan (7) Tanda Daftar Perusahaan (TDP).

Berdasarkan penelitian yang dilakukan, diketahui bahwa pangsa pasar produk Pertashop Pertamina adalah pasar dalam negeri berskala nasional. Penjualan produk Pertashop Pertamina tersebut tidak dilakukan secara langsung oleh PT Riken Engineering Perkasa, melainkan melalui PT Pindad (Persero) yang nantinya barulah di berikan kepada Pertamina. PT Riken Engineering Perkasa mendapatkan pesanan untuk produk Pertashop Pertamina sebanyak 100 unit Pertashop. Berdasarkan tabel di atas diketahui bahwa aspek pasar dan pemasaran PT Riken Engineering Perkasa memenuhi seluruh kriteria dalam aspek pasar dan pemasaran. Mulai dari (1) Tersedianya pangsa pasar ditandai dengan pesanan milik Pertamina Indonesia melalui PT Pindad (Persero), (2) Produk memiliki desain serta rancangan yang telah ditentukan serta memiliki standar pembuatan Pertashop, (3) Harga jual stabil, dan (4) Saluran distribusi sudah tepat, yaitu semua hasil produksi Pertashop dijual kepada PT Pindad (Persero). 
Berdasarkan tabel di atas diketahui bahwa tidak semua kriteria aspek teknis dan teknologi terpenuhi. Dari ke-10 kriteria yang telah ditentukan, terdapat 2 kriteria yang tidak terpenuhi. Namun persentase dari aspek teknis dan teknologi didapatkan $80 \%$ yang itu artinya masih dikatakan layak untuk dijalankan.

Analisis aspek lingkungan hidup dengan klasifikasi pengkategorian diperoleh persentase kelayakan sebesar $75 \%$, hal ini dikarenakan salah satu poin dari aspek lingkungan tidak terpenuhi, poin tersebut adalah menghasilkan limbah yang mengakibatkan polusi suara. Untuk ke-3 poin dari aspek lingkungan dapat dipenuhi oleh PT Riken Engineering Perkasa mulai dari tidak menghasilkan limbah yang mengakibatkan ketidaksuburan tanah, polusi udara, dan perubahan warna, rasa serta bau pada air.

Modal tetap yang harus dikeluarkan PT Riken Engineering Perkasa dalam proyek pembuatan Pertashop Pertamina adalah sebesar Rp. 164.465.000,00. Nominal modal tetap ini didapat diantaranya dari tempat sewa bangunan karena pada workshop PT Riken Engineering Perkasa kekurangan tempat untuk menampung Pertashop. Ukuran produk yang cukup besar dan sulit untuk dipindahkan tentunya memakan ruang yang cukup luas, hal ini mengharuskan PT Riken Engineering Perkasa menyewa sebuah gudang tepat berdekatan dengan workshop PT Riken Engineering Perkasa dengan biaya sewa Rp 150.000.000,00. Adapun peralatan dan mesin penunjang dalam pembuatan Pertashop Pertamina diantaranya terdiri dari meteran, penggaris, alat tulis, mesin gerinda, mesin bor tangan, mesin las blender, mesin las listrik 1600 watt, mesin las argon TIG, dengan umur ekonomis peralatan dan mesin selama 5 tahun ke depan.

Dalam pembuatan Pertashop Pertamina didapati 14 tahap yang dikerjakan PT Riken Engineering Perkasa. Adapun 3 tahap selanjutnya merupakan tahap finishing, yakni tahap pengecoran, pemasangan aksesoris dan terakhir pemasangan cutting sticker. Dari ke-14 proses yang dikerjakan didapati 101 komponen yang dibuat untuk membuat 1 unit Pertashop. Adapun untuk total biaya bahan yang harus dikeluarkan dalam membuat satu unit Pertashop adalah Rp. 49.829.340,00. Biaya tetap dalam pembuatan Pertashop didapati nilai sebesar Rp. 95.322.340. Biaya ini dengan mempekerjakan 9 pekerja dan juga sudah termasuk biaya penyusutan, utilitas, maintenance, dan biaya produksi. Harga pokok penjualan Pertashop didapati senilai Rp. 96.322.340,00 Nilai tersebut didapat dari hasil biaya overhead pabrik yakni hasil penjumlahan biaya tetap dengan biaya tidak tetap. Adapun biaya tidak tetap dari setiap pembuatan satu unit Pertashop adalah Rp. 1.000.000,00. Harga jual dari Pertashop Pertamina adalah dengan kenaikan 30\% dari modal yang dikeluarkan, maka didapati nilai harga jual sebesar Rp. 125.219.041,00. Nilai ini didapati dari keuntungan yang ditargetkan oleh PT Riken Engineering Perkasa adalah berkisar antara 25\% sampai dengan 30\% keuntungan. Harga penjualan Pertashop adalah Rp. 125.219.041,00 dengan HPP Rp. 96.322.340,00, maka didapati keuntungan sebesar Rp. 28.896.702,00. Nilai 1\% dari keuntungan didapati Rp. 2.889.670,00 dengan modal tetap sebesar Rp. 164.465.000,00. Maka nilai 6 Return on investment (ROI) didapat dari persentase $1 \%$ keuntungan dibagi modal tetap yang dikeluarkan didapat ROI sebesar $1,7570 \%$.

Dari analisis yang telah dilakukan, Payback Period proyek Pertashop adalah lebih dari 1 tahun sampai kurang dari 5 tahun yakni selama 57 bulan. Payback Period yang diinginkan untuk PT Riken Engineering Perkasa adalah 5 tahun. Payback Period yang diinginkan tersebut diperoleh dari perkiraan jangka waktu peralatan produksi yang paling lama dapat digunakan, yaitu 5 tahun merupakan perkiraan jangka waktu penggunaan wajar. Dari hasil analisis tersebut, dapat disimpulkan bahwa dilihat dari Payback Period, proyek pembuatan Pertashop dinyatakan layak untuk dijalankan.

Suatu usaha dinyatakan layak untuk dijalankan apabila memiliki nilai 8. Net Present Value (NPV) lebih besar dari nol. Pada proyek pembuatan Pertashop didapati NPV sebesar Rp. 833.980.124,00 untuk 5 tahun ke depan. Dari analisis yang dilakukan, NPV menghasilkan nilai lebih besar dari nol. Dengan demikian dapat disimpulkan bahwa dilihat dari nilai NPV, proyek pembuatan Pertashop dinyatakan layak untuk dijalankan.

Berdasarkan analisis yang dilakukan, Profitability Index (PI) menghasilkan nilai lebih besar dari 1 dengan nilai 1,1185. Nilai PI tersebut didapat dengan jumlah arus kas bersih 5 tahun sebesar Rp1.116.841.900,00 dengan jumlah PV Rp998.445.124,00. Dengan demikian dapat disimpulkan bahwa dilihat dari nilai PI, proyek pembuatan Pertashop dinyatakan layak untuk dijalankan.

Tingkat keuntungan yang dikehendaki merupakan tingkat suku bunga Bank Indonesia pada periode usaha dijalankan yang diperoleh dari yang telah diolah, yaitu sebesar 7\%. Dari hasil penelitian, Internal Rate of Return (IRR) menghasilkan nilai lebih dari tingkat bunga yang diinginkan. Dengan demikian dapat disimpulkan bahwa diihat dari nilai IRR, proyek pembuatan Pertashop dinyatakan layak untuk dijalankan.

Suatu usaha dinyatakan layak untuk dijalankan jika memiliki nilai Average Rate of Return (ARR) lebih besar dari minimum accounting rate of return. Minimum accounting rate of return untuk PT Riken Engineering Perkasa adalah $10 \%$, ARR menghasilkan nilai sebesar 9,48\%. Dengan demikian dapat disimpulkan bahwa dilihat dari nilai ARR, proyek pembuatan Pertashop masih dapat dinyatakan belum layak untuk dijalankan. 


\section{KESIMPULAN}

Setelah melakukan analisis kelayakan usaha proyek pembuatan Pertashop, maka kesimpulan yang diperoleh adalah sebagai berikut: (1) Ditinjau dari aspek hukum PT Riken Engineering Perkasa, proyek pembuatan Pertashop dinyatakan sangat layak untuk dijalankan, (2) Ditinjau dari aspek pasar dan pemasaran, proyek pembuatan Pertamina dinyatakan sangat layak untuk dijalankan, (3) Ditinjau dari aspek teknis dan teknologi, proyek pembuatan Pertamina dinyatakan sangat layak untuk dijalankan, (4) Ditinjau dari aspek lingkungan hidup, proyek pembuatan Pertamina dinyatakan sangat layak untuk dijalankan. proyek pembuatan Pertashop Pertamina tidak menimbulkan dampak kerusakan lingkungan, dan (5) Ditinjau dari aspek finansial yang dianalisis melalui metode PaybackaPeriod (PP), Net Present Value (NPV), Profitability Index (PI), Internal Rate of Return (IRR), dan Average Rate of Return (ARR), proyek pembuatan Pertamina dinyatakan sangat layak dijalankan.

Berdasarkan hasil penelitian, didapati hasil yang tidak terlalu jauh dari batas kelayakan usaha, seperti halnya pada aspek finansial waktu pengembalian modal yang hampir mencapai 5 tahun, merupakan batas maksimal pengembalian investasi. Berdasarkan teknis dan teknologi untuk pembuatan satu unit Pertashop Pertamina memerlukan waktu selama satu bulan, yang mana waktu ini masih terpaut jauh dari target produksi awal yakni selama 14 hari. Beberapa hal tersebut setelah di analisis dapat disimpulkan produksi Pertashop Pertamina masih pada batas layak untuk dijalankan oleh PT Riken Engineering Perkasa.

\section{PENGHARGAAN}

Penelitian ini dapat dilaksanakan dengan baik berkat bantuan dari berbagai pihak, untuk itu penulis mengucapkan terima kasih kepada seluruh pihak dari PT Riken Engineering Perkasa meliputi HRD, PPIC, Engineer, Kepala Departemen, staff dan operator, pembimbing lapangan, dosen pembimbing kerja praktek dari Program Studi Teknik Industri UNSIKA yang telah memberikan kerjasama yang baik dalam penelitian ini.

\section{DAFTAR PUSTAKA}

AbidatulaAfiyah, d. (2015). Analisis Studi Kelayakan Usaha Pendirian Home Industry (Studi Kasus pada Home Industry Cokelat "Cozy" Kademangan Blitar). JurnalaAdministrasi Bisnis (JAB), 1-11.

Azanella, L. A. (2020). Kompas.com. Retrieved from Kompas.com: https://www.kompas.com/tren/read/2020/11/20/141653765/mengenal-tentang-pertashop-keuntungansyarat-dan-cara-daftarnya

Dewi Purnamasari, B. H. (2013). Analisis KelayakanaBisnis Usaha Roti Ceriwis sebagai Oleh-Oleh Khas Kota Batam. Jurnal Akuntansi, Ekonomi dan Manajemen Bisnis, 83-87.

Eko Suwito Handjojo, R. S. (2017). Analisis Kelayakan Bisnis UsahaaTeh Papua (Vernonia amygdalina). Jurnal ManajemenaIKM, 145-150.

I Made Yogi Winantara, A. B. (2014). Analisis Kelayakan Usaha Kopi Luwak Di Bali. Jurnal Online Institut Teknologi Nasional, 118-129.

Irna Novia Fitriani, d. (2013). Studi Kelayakan Bisnis Bakso Lotus Jembar. Jurnal Gastronomi Wisata, 1-11.

Kadek Arianton, M. A. (2019). Studi Kelayakan Usaha Budidaya Rumput Laut pada Kelompok Bina Karya di Desa Patas, Kecamatan Gerokgak, Kabupaten Buleleng. Jurnal Pendidikan Ekonomi, 573-582.

Kasmir, J. d. (2012). Studi Kelayakan Bisnis. Jakarta: Kencana Prenada Media Group.

Lukas Ardianto Tanaka, M. A. (2017). Studi Kelayakan Bisnis Uniquephotocard di Mal Ciputra World Surabaya. PERFORMA: Jurnal Manajemen dan Start-Up Bisnis, 746-754.

Musmulyadi. (2020). Analisis Studi Kelayakan Bisnis Usaha Waralaba dan Citra Merek Terhadap Keputusan Pembelian "Alpokatkocok_Doubig” di Makassar. PAY Jurnal Keuangan dan Perbankan.

Opan Arifudin, d. (2020). Studi Kelayakan Bisnis Telur Asin H-Organik. Jurnal Ecodemica, 341-352.

Rahayu, A. D. (2015). Analisis Kelayakan Usaha Gula Sumut Anggota Koperasi Serba Usaha (KSU) Jatirogo. Yogyakarta: Program Studi Akuntansi Jurusan Pendidikan Akuntansi Fakultas Ekonomi Universitas Negeri Yogyakarta. 
Risal Rinofah, I. S. (2016). Analisis Kelayakan Usaha Warung "BURJO" (Studi Kasus di Dusun Karang Gayam, Catur Tunggal, Depok Sleman, Yogyakarta). JKB, 1-11.

Sapmaya Wulan, .. B. (2016). Analisis Studi Kelayakan Rencana Usaha Kuliner Rumah Makan Nusantaraku di Lampung Tengah. Jurnal Manajemen dan Bisnis, 192-215.

Siti Rahmadani, M. (2019). Analisis Studi Kelayakan Bisnis pada Pengembangan UMKM Usaha Tahu dan Tempe Karya Mandiri ditinjau dari Aspek Produksi, Aspek Pemasaran dan Aspek Keuangan. Jurnal Ilmiah Manajemen dan Bisnis, 76-83.

Sofyan, I. (2003). Studi Kelayakan Bisnis. Yogyakarta: Graha Ilmu.

Suliyanto. (2010). Studi Kelayakan Bisnis. Yogyakarta: CV. ANDI OFFSET.

Winda Amilia, M. C. (2017). Studi Kelayakan Usaha dan Daya Saing Pada Industri Tepung Tapioka di Kecamatan Pogalan Kabupaten Trenggalek Study Of Feasibility And Competitive Advantage On Tapioca Flour Industry In Pogalan, Trenggalek. JSEP, 51-57.

Yusri Nadya, D. I. (2018). Analisis Studi Kelayakan Usaha Penggilingan Padi pada Desa Sungai Kuruk I. Jurutera, 32-41. 